\title{
A NEW ORIBATID MITE OF THE GENUS PELORIBATES BERLESE, 1908 (ACARI, ORIBATIDA, HAPLOZETIDAE) FROM MONGOLIA
}

\author{
B. Bayartogtokh $(*)$
}

\begin{abstract}
In the course of study on the species diversity and ecology of oribatid mites of Mongolia one interesting species belonging to the genus Peloribates was found and is described here as new to science. The new species, Peloribates angulatus differs from the closely related species by the relatively long and narrow head of sensillus, the different number of genital setae; the presence of distinct angular projection on the lateral margins of ventral plate, the presence of network consisting numerous striations and muscle sigillae on the anterolateral part of notogaster, the different arrangement of notogastral setae and the larger body size.
\end{abstract}

Key words: Acari, Oribatida, Haplozetidae, Peloribates angulatus nov. sp., Mongolia.

\section{RESUMEN * *}

Nueva especie de ácaro oribátido del género Peloribates Berlese, 1908 (Acari, Oribatida, Haplozetidae) de Mongolia

Durante la realización de estudios sobre la diversidad y ecología de los ácaros oribátidos de Mongolia se encontró una interesante especie del género Peloribates que aquí se describe como nueva para la ciencia. La nueva especie, Peloribates angulatus, se diferencia de las especies próximas por la morfología de la cabeza del sensilo: relativamente larga y estrecha, el distinto número de setas genitales, la presencia de una marcada proyección angular en el margen lateral de la placa ventral, la existencia en el área anterolateral del notogáster de un retículo formado por múltiples estriaciones e impresiones musculares, la diferente disposición de las setas notogastrales y un mayor tamaño corporal.

Palabras clave: Acari, Oribatida, Haplozetidae, Peloribates angulatus sp. nov., Mongolia.

\section{Introduction}

This work is part of a continuing study of oribatid mite fauna of Mongolia, and the present paper contains the description of a new species belonging to the genus Peloribates. The genus Peloribates was established by Berlese (1908) with Oribates peloptoides Berlese, 1888 as the type species. The diagnostic characteristics of this genus are considered to be the following: adults small to large in size (240-620 mm); notogaster with 14 pairs of setae; four pairs of sacculli; pteromorphae movable, fully

* Present address: Department of Soil Zoology, Institute of Environmental Science and Technology, Yokohama National University, Yokohama 240-8501, Japan. Tel. 81-45-339-4357. Fax-81-45-339-4375. E-mail: bayara@kan.ynu.ac.jp Permanent address: Department of Zoology, Faculty of Biology, National University of Mongolia, Ulaanbaatar 210646, Mongolia.

** Tanto el resumen en castellano como los pies de figura en este mismo idioma han sido redactados por la revista. 


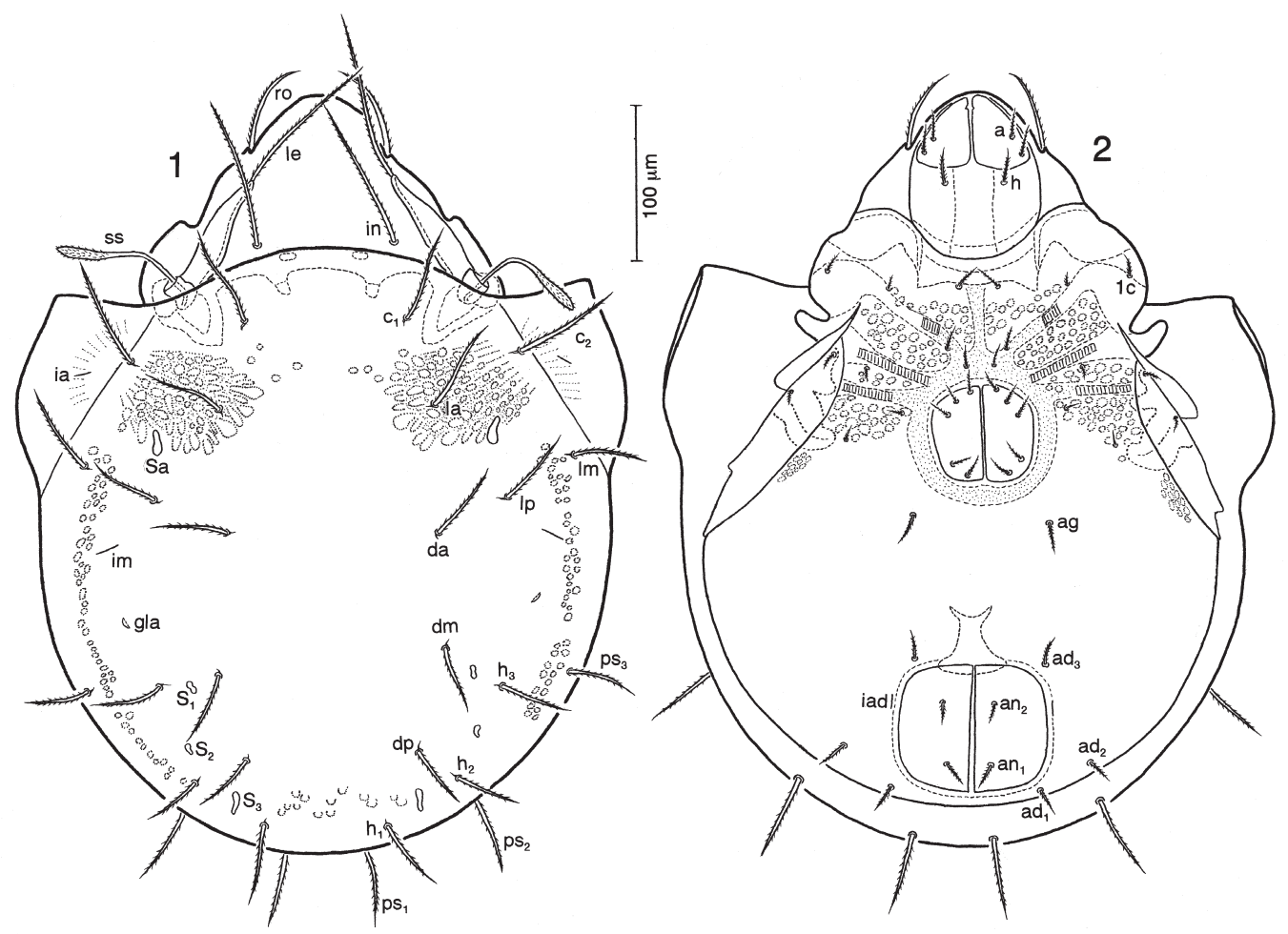

Figs. 1-2.- Peloribates angulatus sp. nov.: 1) Dorsal aspect. 2) Ventral aspect.

Figs. 1-2.- Peloribates angulatus sp. nov.: 1) Aspecto dorsal. 2) Aspecto ventral.

hinged; lamellae well-developed; the true translamella is absent or lineate, never completely crossing space between lamellar setae; five pairs of genital setae; one or three pairs of aggenital setae; legs usually tridactylous, but rarely monodactylous.

The genus Peloribates is comparatively species rich, and world-wide, more than eighty species are assigned to this genus, which were previously known from widely scattered areas of most of the biogeographical regions. Several species have wide distribution and majorities have been described from Palaearctic, Nearctic and Oriental regions. On the basis of present knowledge the genus appears to be poorly represented in the Neotropical, Ethiopian and Australian regions. In addition, I describe below a new species from the Northern Mongolia under the name of Peloribates angulatus sp. nov.

All measurements are given in micrometers $(\mu \mathrm{m})$, and average measurement is given in brackets after the range.
Peloribates angulatus sp. nov.

(Figs. 1-20)

Material eXAmined. Holotype (female) and 14 paratypes (8 males and 6 females) from litter of pine forest (Pinus silvestris) in "Tujiin Nars" area, District Shaamar, Province Selenge, Mongolia, 506N, $106^{\circ} 10^{\prime} \mathrm{E}, 1430 \mathrm{~m}, 23$ May, 1993, Leg. B. Bayartogtokh.

TYPE DEPOSITORY. The holotype and 10 paratypes are deposited in the Acarology collection of the Department of Zoology, National University of Mongolia, Ulaanbaatar, Mongolia; 2 paratypes are deposited in the collection of Museo Nacional de Ciencias Naturales (MNCN 20.02/9957), Madrid, Spain, and 2 paratypes in the collection of National Science Museum, Tokyo, Japan.

DiagNosis. Medium in size, with typical characters of Peloribates. Rostrum broadly rounded; lamellae relatively wide, but distinctly narrowed toward the distal end; all prodorsal setae rather long and distinctly barbed; sensillus with a minutely barbed lanceolate head and a smooth, narrow stalk. 
Fourteen pairs of notogastral setae conspicuously barbed bilaterally; four pairs of sacculi irregularly oval in shape; pteromorphae well-developed, fully hinged. Lateral margins of ventral plate with distinctly developed angulation on each side. Five pairs of genital, one pair of aggenital, two pairs of anal and three pairs of adanal setae. All tarsi heterotridactylous. The immatures are unknown.

COLOR. Yellowish brown to deep reddish brown.

Measurements. Body length 476-512 (490.8) $\mu \mathrm{m}$; width of hysterosoma 360-384 (373.7) $\mu \mathrm{m}$; length of proterosoma 92-116 (106.2) $\mu \mathrm{m}$; width of proterosoma 208-237 (223.5) $\mu \mathrm{m}$; length of hysterosoma 360-406 (385.5) $\mu \mathrm{m}$.

Prodorsum. Shape of prodorsum more or less triangular, its dorsal surface smooth. Rostrum broadly rounded anteriorly. Rostral setae rather long and thick, densely barbed unilaterally. They are inserted laterally, well extending beyond the tip of rostrum. Lamellae relatively wide, but distinctly narrowed toward the distal end; the length of lamellae is nearly as long as half of the total length of prodorsum. Lamellar setae long, distinctly barbed and extending for $1 / 2$ of their length beyond the tip of rostrum. Interlamellar setae also rather long and thick, but scarcely shorter than the lamellar ones; densely barbed throughout their length. Insertions of interlamellar setae situated anterior to dorsosejugal suture (Figs. 1, 3). Sensillus with weakly swollen lanceolate head minutely barbed and a smooth, narrow stalk (Figs. 1, 4). Total length of sensillus nearly as long as that of interlamellar seta. Bothridium directed anterolaterally, posterior part is concealed under anterior margin of notogaster. The bothridium is surrounded anteriorly and ventrally by distinct rugae, and on its wall is a distinct carina (Figs. 3, 4).

NotOGASTER. Shape of notogaster rounded, slightly longer than wide. Surface of notogaster nearly smooth, but numerous muscle sigillae scattered along the lateral and posterior margins. The anterolateral part of notogaster exhibits on each side, through the integument, a kind of network which consisting of many light spots, punctures and a few striations radiating from the humeral region (Figs. 1, 5). Pteromorphae well-developed, fully hinged, with dorsal surface weakly striated. Fourteen pairs of notogastral setae fairly long and thick, distinctly barbed bilaterally. Setae $c_{1}$ and $c_{2}$ scarcely longer than remaining notogastral setae
(Figs. 1, 6-11). Four pairs of sacculi somewhat irregularly oval in shape; $S a$ far larger than others. Sacculus $S a$ situated anteriorly to seta $l p, S_{1}$ posterolaterad to seta $d m, S_{2}$ and $S_{3}$ situated anterolaterally to setae $h_{2}$ and $h_{1}$, respectively (Figs. 1, 5, 1215). Lyrifissures $i a$ and $i m$ well developed; $i a$ situated under the pteromorphae; im located posterolaterally to each seta $l p$. Lateroabdominal gland opening gla situated posteromedially to im (Fig. 1).

GNATHOSOMA. Subcapitulum and palps normal for the genus. Chelicerae also normally developed, with chitinized teeth (Fig. 16). Hypostomal surface smooth, one pair of fairly long and thick hypostomal setae $h$ distinctly barbed bilaterally; maxillar setae $m$ and $a$ also rather long and thick, densely barbed bilaterally (Fig. 2).

EPIMERAL REGION. Surface of epimeral region with a number of round muscle sigillae and a small dot shaped punctures. Apodemata apo.sj and apo.3 well-developed, rather long, aligned obliquely, while apo. 2 very short. Epimeral setae relatively short, but rather thick and distinctly barbed bilaterally. Setal formula of epimerata: 3-1-3-3. Carina circumpedalis well-developed; lateral margins of ventral plate with a distinct angular projection (like teeth) on its each side, at the level of aggenital setae (Fig. 2). Pedotectum I large, outer margin rounded, its surface smooth; pedotectum II relatively small, nearly rounded.

ANO-Genital REgion. Surface of ventral plate and also anal and genital plates smooth. Anal and genital apertures situated far from each other, the former one is far larger than the other. Six pairs of genital setae fairly long and bilaterally barbed; one pair of aggenital setae situated lateroposterior to genital aperture. Distance between bases of aggenital setae nearly equal to that of between setae $a d_{3-}$ $a d_{3}$. Two pairs of anal and three pairs of adanal setae rather long, thick, densely barbed bilaterally; seta $a d_{3}$ in preanal position. Adanal lyrifissures iad situated adjacent and parallel to each lateral margin of anal aperture (Fig. 2).

LEGS. All tarsi heterotridactylous, with the lateral claws much thinner than the empodial claw; dorsal surface of claws smooth, without any serration. Tibia I with distinct scale-like spur on its ventral side. Femora II-IV have distinct, complete ventral keels or blades, which are distally rounded. Femur I with a short, relatively narrow keel in its distal part, around the seta $v$ ". Femora I-III with 


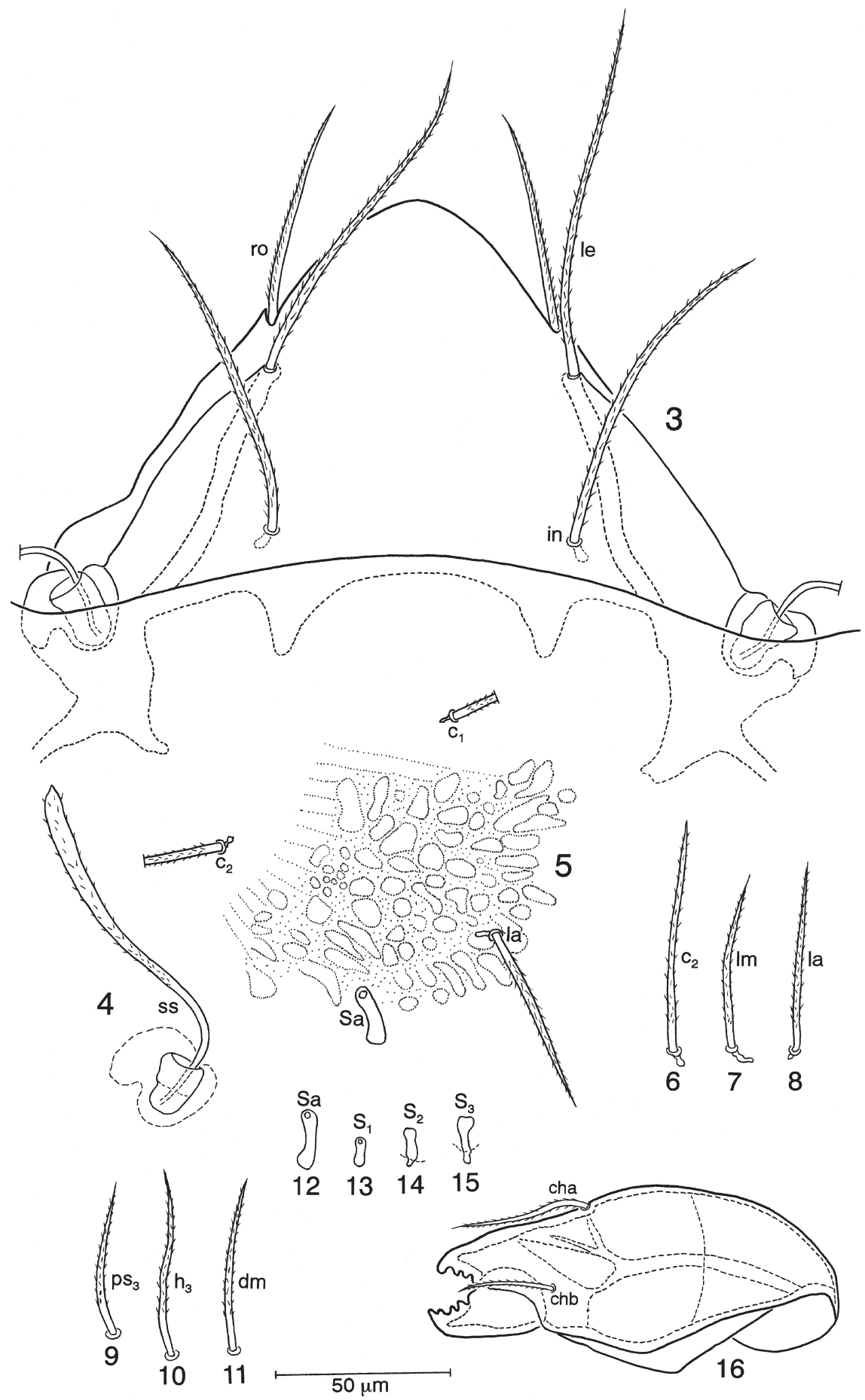

Figs. 3-16.- Peloribates angulatus sp. nov.: 3) Prodorsum. 4) Sensillus and bothridium. 5) Network on the anterolateral part of notogaster. 6) Notogastral seta $c_{2}$. 7) Notogastral seta $l m$. 8) Notogastral seta la. 9) Notogastral seta $p s_{3}$. 10) Notogastral seta $h_{3}$. 11) Notogastral seta $d m$. 12) Sacculus $S a$. 13) Sacculus $S_{1}$. 14) Sacculus $S_{2}$. 15) Sacculus $S_{3}$. 16) Chelicera.

Figs. 3-16.- Peloribates angulatus sp. nov.: 3) Prodorsum. 4) Sensilo y botridio. 5) Retículo sobre la zona anterolateral del notogáster. 6) Seta notogastral $c_{2}$. 7) Seta notogastral $l m$. 8) Seta notogastral la. 9) Seta notogastral $p s_{3}$. 10) Seta notogastral $h_{3}$. 11) Seta notogastral $d m$. 12) Sacculus $S a$. 13) Sacculus $S_{1}$. 14) Sacculus $S_{2}$. 15) Sacculus $S_{3}$. 16) Quelíceros. 

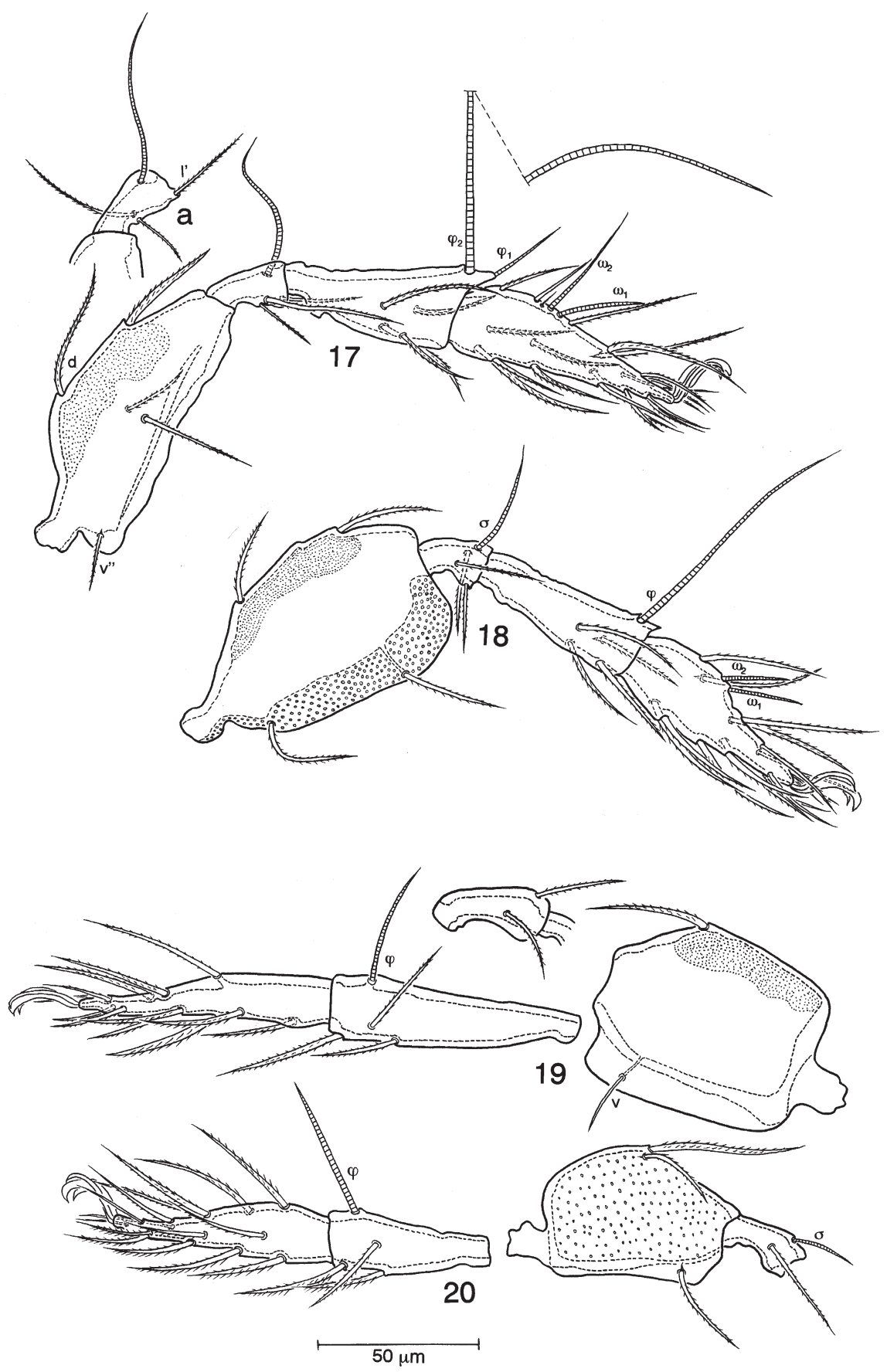

Figs. 17-20.- Peloribates angulatus sp. nov.: 17) Leg I (right, antiaxial aspect); 17a) Genu of leg I, showing the dorsal projection around insertion of seta $l$; 18) Leg II (right, antiaxial aspect); 19) Leg IV (left femur, tibia and tarsus, and right genu, antiaxial aspect); 20) Leg III (right femur, genu, and left tibia, tarsus, antiaxial aspect).

Figs. 17-20.- Peloribates angulatus sp. nov.: 17) Pata I (derecha, posición antiaxial); 17a) Genu de la pata I, muestra la proyección dorsal alrededor de la inserción de la seta $l$; 18) Pata II (derecha, posición antiaxial); 19) Pata IV (fémur, tibia y tarso izquierdos y genu derecho, posición antiaxial); 20) Pata III (fémur y genu derechos, tibia y tarso izquierdos, posición antiaxial). 
large areae porosae, and femora II and III with distinct granulation. All setae on the leg segments, except seta $v$ of femur IV are distinctly barbed. On tarsus I solenidion $\omega_{2}$ slightly longer than $\omega_{1}$; famulus $\varepsilon$ short and slender, situated behind $\omega_{2}$. Tibia I with an extremely long and thick solenidion $\varphi_{2}$, and a short $\varphi_{1}$ inserted on the distinctly projected apophysis. Genu I with fairly long solenidion $\sigma$, and a distinct ventral projection for seta l' (Fig. 17a). Dorsal seta $d$ on femur I in proximal third. Solenidia $\omega_{1}$ and $\omega_{2}$ on tarsus II almost equal in length. Anterodorsal end of tibia II with short, but sharply pointed projection. Solenidion $\varphi$ on tibia II about 3.5 times as long as $\omega_{1}$ of tarsus II. The formula of leg setation including famulus: I (1-5-3-420); II (1-4-3-4-15); III (2-3-1-3-15); IV (1-2-2-312) and the formula of solenidia: I (1-2-2); II (1-12); III (1-1-0); IV (0-1-0). Setation of legs I-IV as shown in Figs. 17-20.

Remarks. Among the known species of the genus Peloribates, only $P$. porosus Beck, 1964, P. dispersus Beck, 1964, P. europaeus Willmann, 1935 and P. pilosus Hammer, 1952 resemble the new species in general appearance and in the length of notogastral setae. However, the new species is easily distinguishable from $P$. porosus, described from Peru by the relatively long and narrow head of sensillus; the long interlamellar setae; the relatively wide lamellae; the different arrangement of notogastral setae $l a, l p$ and $d a$; the presence of distinct network consisted of numerous striations and muscle sigillae on each anterolateral side of notogaster; the different shape (irregularly oval) of sacculi; the lacking of transverse ridge between distal end of lamellae; the smoothly rounded shape of ventral keel of femur II; the presence of distinct angular projections on the lateral margins of ventral plate; and the far large body size. The other South American species - P. dispersus can also be distinguished from the new species in the clavate head of sensillus; the notogastral seta $l p$ and $d p$ situated far anteriorly and posteriorly of its usual position, respectively; the narrow and elongated shape of notogaster; the relatively long notogastral setae; and the small body size. The new species differs from $P$. europaeus, described from Austria and later reported from many different areas of Palaearctic region by the presence of five pairs of genital setae $(P$. europaeus with four pairs of genital setae); the relatively long interlamellar and notogastral setae; the narrow and long sensillus; the presence of network consisting numerous striations and muscle sigillae on the anterolateral part of notogaster; the presence of conspicuous angular projections on the lateral margins of ventral plate; and the far large body size. The last species - P. pilosus, described from North America and later reported from Europe and Siberia differs from the new species by the smooth dorsal surface of notogaster; the presence of transverse line in front of lamellae; the relatively narrow rostrum; the smooth ventral setae; and the absence of angular structure on the lateral margins of ventral plate.

ETymology. The specific epithet "angulatus" is referring to the distinctly developed outer angular projections on the lateral margins of ventral plate in adults of this species.

\section{Acknowledgements}

I would like to express my sincere gratitude to Prof. Junichi Aoki, Yokohama National University, Yokohama, for his valuable advice and encouragement. This study was supported by the Japan Society for the Promotion of Science.

\section{References}

BECK, L., 1964. Beiträge zur kenntnis der Neotropischen oribatidenfauna. 4. Haplozetes und Peloribates (Arach., Acari). Senckenbergiana Biologica, 45: 161183.

Berlese, A., 1888. Acari Austro-Americani quos collegit Aloysius Balzan. Manupulus primus. Species novas circiter quinquaginta complectens. Bollettino della Società Entomologica Italiana, 20: 171-222, pls. 5-13 (sep. pp. 1-52).

Berlese, A., 1908. Elenco di generi e specie nuove di Acari. Redia, 5: 1-15.

HAMmer, M., 1952. Investigations on the microfauna of northern Canada. Part I: Oribatidae. Acta Arctica, 4: 1-108.

Willmann, C., 1935. Die Milbenfauna. 1. Oribatei. In: Faunistisch-ökologische Studien im Anningergebiet, mit besonderer Berucksichtigung der xerothermen Formen. Zoologische Jahrbücher. Abteilung für Systematik, Ökologie und Geographie der Tiere, 66: 331-344. 